\title{
Perils of Success? The Case of International Investment Protection
}

\author{
Anne van Aaken*

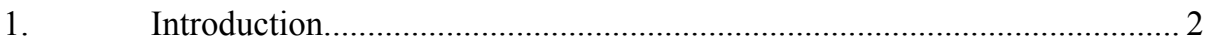 \\ 2. International investment law: an overview ............................................ 4 \\ 3. The success of international investment law.......................................... 8

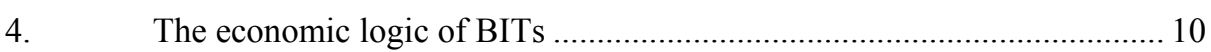

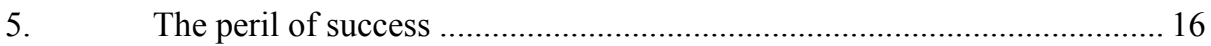

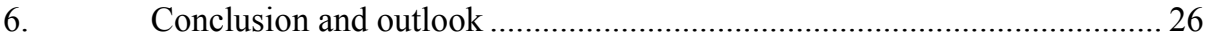

\begin{abstract}
Foreign direct investment forms an ever more important part of globalised market structures, and international investment law has become one of the most successful and judicialised areas of public international law. In order to attract investment, States commit themselves to treaties that restrict their regulatory sovereignty in ways that are sometimes unpredictable, owing to vague terms in the treaties and the broad use by investment tribunals of their delegated discretion.

This article uses economic contract theory in order to understand whether the commitment problem ex ante and the flexibility problem ex post are optimally solved. It is hypothesised that the participation constraints on States may be overlooked by investment tribunals, thereby leading to an undesired weakening of protection of investors in the long run due to reactions by States. First, States may opt out of the system, for example by exiting treaties or by non-compliance. Second, they may also water down the substantive or procedural protections. Third, whereas investment treaties were seen in the beginning as a restraint on developing countries, investment increasingly flows to equally highly regulated developed countries. As legal protection is reciprocal but the capital flows used
\end{abstract}

\footnotetext{
* Max Schmidheiny Tenure Track Professor of Law and Economics, Public Law, International and European Law at the University of St. Gallen, Switzerland, Guisanstrasse 36, CH9010 St. Gallen, e-mail: anne.vanaaken@unisg.ch. I would like to thank the participants of the Amsterdam Center for Law and Economics (ACLE) workshop, the participants of the faculty workshop of Vanderbilt Law School as well as Christoph Engel, Larry Helfer, Christian Kirchner, Rekha Oleschak, Stephan Schill and Stefan Voigt for helpful comments.
} 
to be unilateral, developed countries might also react to their restriction of sovereignty, as the United States has already done, for example. These perils could lead to a backlash in international investment protection of which indications are already visible.

Keywords: international investment law, contract theory, fragmentation, mechanism design.

1.

\section{INTRODUCTION}

Public international law (PIL) sometimes suffers from ineffectiveness; a phenomenon sometimes used to declare PIL epiphenomenal ${ }^{1}$ or to construct rationally designed international institutions in order to make it more effective. ${ }^{2}$ Traditionally, international lawyers have only rarely asked questions about effectiveness, ${ }^{3}$ and, if they do, they usually assume that the more effective the law is, the better. But could PIL also become too successful? International investment law is one of the issue areas of PIL that has been evolving and legalising rapidly and has been very successful. ${ }^{4}$ Over the past fifteen years, we have seen an ongoing surge in the conclusion of bilateral investment treaties (BITs) $)^{5}$ in absolute terms - though with a decline in relative terms since 1996 - as well as a surge in international arbitration of investment disputes at around the same time. ${ }^{6}$

1 For example, in the realist tradition in PIL and lately also in the Law and Economics tradition. See J.L. Goldsmith and E.A. Posner, The Limits of International Law (Oxford, Oxford University Press 2005); for a review of the latter, see A. van Aaken, 'To Do Away with International Law? Some Limits to "The Limits of International Law", 17 EJIL (2006) p. 289.

2 For example, B. Koremenos, et al., 'The Rational Design of International Institutions', 55 International Organization (2001) p. 761.

3 Effectiveness and compliance are different but related notions. Determining whether a State complies with a treaty requires comparing the relevant State's activity with the treaty's requirements. Effectiveness is directly related to - but distinct from - compliance and relates to causality. A State may comply with a treaty, that is to say, its actions may comport with the requirements of the treaty, but the treaty may nonetheless be ineffective in changing that State's practices. On these notions, see A.T. Guzman, 'A Compliance-Based Theory of International Law', 90 California Law Review (2002) p. 1823; on compliance theories, see H.H. Koh, 'Why do Nations Obey International Law?', 106 Yale Law Journal (1997) p. 2599; and L.R. Helfer and A.-M. Slaughter, 'Toward a Theory of Effective Supranational Adjudication', 107 Yale Law Journal (1997) p. 273.

${ }^{4}$ By success I mean that the regime is used by the relevant actors, that is to say, States and foreign direct investors.

5 From 1990 to 2004, there was a surge from less then 500 BITs to almost 2,500 BITs, see UNCTAD, World Investment Report (New York/Geneva, United Nations 2006) at pp. 26 and 29. If investment chapters of regional trade agreements, such as NAFTA, are included, there is even more treaty-making activity in the investment protection area (p. 28).

6 UNCTAD, supra n. 5. 
From an international lawyer's perspective, this is a perfect development. But this may only be true at first sight. If substantive rules or review mechanisms place too much of a constraint on sovereignty, this might precipitate a backlash by governments. If so, when are those counter-reactions likely to occur and how can they be avoided?

According to economic contract theory, BITs may be interpreted as a mechanism for overcoming commitment problems between the investor and the host State in order to generate mutual benefits. A State promises not to infringe on the property rights of foreign direct investors in order to attract more investment and ultimately foster development. States thereby trade credibility for sovereignty, as international investment law restricts the regulatory conduct of States to an unusual extent, subject to control through compulsory international adjudication. ${ }^{8}$ A well-known problem in contract theory is how to deal with uncertainty. ${ }^{9}$ Parties cannot easily design contracts that maximise jointly beneficial investments and at the same time respond appropriately to changing conditions ex post. Thus, a trade-off arises between ex ante strong commitment devices, on the one hand, and flexibility ex post in order to uphold the efficiency of the contract, on the other hand. But changing conditions are a prevalent characteristic in investment law. Contract theory finds that excessively strict and inflexible contracts may impair the joint surplus of the contracting parties. A problem one can identify is that, over the last years, the costs of BITs for States have been increasing, primarily due to progressive interpretation by international arbitral tribunals, granting little flexibility ex post. Hence, a trade-off may be identified. On the one hand, existing BITs are made more powerful in protecting investments due to progressive interpretation by international arbitral tribunals (thereby mitigating the commitment problem). On the other hand, this development might endanger the future of BITs and thereby the protection of foreign direct investment (FDI) due to high sovereignty costs. In the language of mechanism design, investment protection

7 For similar research on international human rights treaties, see L.R. Helfer, 'Overlegalizing Human Rights: International Relations Theory and the Commonwealth Caribbean Backlash Against Human Rights Regimes', 102 Columbia Law Review (2002) p. 1832.

${ }^{8}$ G. van Harten and M. Loughlin, 'Investment Treaty Arbitration as a Species of Global Administrative Law', 17 EJIL (2006) p. 121, who draw an analogy with domestic administrative law rather than international commercial arbitration, since investment arbitration engages disputes arising from the exercise of public authority by the State as opposed to private acts of the State. This analogy is also supported in Separate Opinion of T. Wälde in International Thunderbird Gaming Corporation v. Mexico, NAFTA by UNCITRAL Rules (26 January 2006) paras. 13, 27, 129 and 139.

9 For a thorough treatment of uncertainty in international relations, especially concerning the capacity of States to implement international treaties in internal policies, see G.W. Downs and D.M. Rocke, Optimal Imperfection? Domestic Uncertainty and Institutions in International Relations (Princeton, Princeton University Press 1995); for uncertainty in contracts as applied to international law, see R.E. Scott and P.B. Stephan, The Limits of Leviathan. Contract Theory and the Enforcement of International Law (Cambridge, Cambridge University Press 2006). 
lawyers sometimes seem to overlook the participation constraints on States. States can and already do react to this trade-off in various ways if they think that the pendulum has swung too far. It is hypothesised that 'overprotection' of foreign investment may lead to reactions that in the long run will weaken investment protection. In other words, international investment law has possibly passed a threshold of protection for foreign direct investors that endangers the system as a whole and may therefore lead to the ultimately undesired result of less protection for FDI in the long run.

This paper is organised as follows. First, section 2 provides a short overview on the functioning of international investment law. Section 3 takes a brief look at the success of international investment law and the empirical evidence of the impact of BITs on FDI. Section 4 sketches the economic logic of BITs, drawing on rational choice theory, especially economic contract theory applied to international relations. Section 5 deals with the peril of success and the possible reactions of States. The final section concludes by presenting some suggestions on how the perils may be mitigated.

Whereas international trade in goods and services is mainly governed by the WTO Agreement and its Annexes, there is no international legal equivalent for the governance of international investment, which constitutes a big part of international capital flows. ${ }^{10}$ So far, several attempts to draft an international agreement have failed. Most recently, the Draft Multilateral Agreement on Investment, negotiated under the auspices of the OECD, failed spectacularly in 1998. ${ }^{11}$ Likewise, the attempt to negotiate this topic under WTO auspices failed for the time being when the so-called 'Singapore issue' of investment was taken off the negotiating agenda of the Doha Round in the summer of 2004. ${ }^{12}$ Thus,

10 From 1982 to 2005, FDI outward stock increased from USD 600 billion to 10,672 billion, thereby outpacing the increase in trade. See UNCTAD, supra n. 5, Table I.2.

${ }_{11}$ In 1995, OECD ministers launched negotiations on a multilateral agreement on investment (MAI) that had high standards of liberalisation and investment protection, effective dispute settlement procedures, and was open to non-members. Negotiations were discontinued in April 1998 and will not be resumed. For the negotiating history and reasons for failure, see R. Geiger, 'Towards a Multilateral Agreement on Investment', 31 Cornell International Law Journal (1998) p. 467. For the text of the draft, see: $<$ http://www.oecd.org/dataoecd/46/40/ 1895712.pdf>.

12 At the 1996 Singapore Ministerial Conference, ministers from WTO member countries decided to set up new working groups on: trade and investment, competition policy, transparency in government procurement and trade facilitation. These four subjects were originally included on the Doha Development Agenda. The carefully negotiated mandate was for negotiations to start after the 2003 Cancún Ministerial Conference, 'on the basis of a decision 
there are no encompassing multilateral legal rules for foreign direct investment. The legal protection of foreign property nevertheless has a long history, ${ }^{13}$ with customary international law (CIL) protecting foreigners, including investors, by means of the so-called 'minimum standard of treatment"14 and compensation requirements for expropriations. ${ }^{15}$ But this protection - nomen est omen - is only minimal and does not live up to the modern requirements of protection, as the interference with property rights is much more refined nowadays. Most contentious issues deal not with outright expropriation but rather with regulatory expropriation or unfair treatment and disputes over contractual rights elevated to international law claims.

Nonetheless, this does not mean that foreign investment is legally unprotected - on the contrary. Since the conclusion of the first BIT between Germany and Pakistan in 1959, foreign investment is governed ever more by BITs as well as by bilateral or regional free trade agreements (FTAs) that include chapters on investment protection, such as NAFTA. ${ }^{16}$

to be taken, by explicit consensus, at that session on modalities of negotiations'. There was no consensus, and the members agreed on 1 August 2004 to drop the issues (except for trade facilitation) from the Doha Agenda.

13 For an overview, see A.F. Lowenfeld, International Economic Law (Oxford, Oxford University Press 2002) at pp. 391-414.

14 For a discussion of the CIL character of protective norms in BITs, see B. Kishoiyian, 'The Utility of Bilateral Investment Treaties in the Formulation of Customary International Law', 14 Northwestern Journal of International Law and Business (1994) p. 327; A. A1 Faruque, 'Creating Customary International Law through Bilateral Investment Treaties: A Critical Appraisal', 44 Indian Journal of International Law (2004) p. 292, both arguing against the formation of CIL through BITs; see also M.C. Porterfield, 'An International Common Law of Investors Rights?', 27 University of Pennsylvania Journal of International Economic Law (2006) p. 79, arguing against the acceptance of even the minimum standard of treatment as a CIL norm due to its vagueness. For arguments in favour of the formation of CIL through BITs, see S. Hindelang, 'Bilateral Investment Treaties, Custom and a Healthy Investment Climate The Question of Whether BITs Influence Customary International Law Revisited', 5 Journal of World Investment and Trade (2004) p. 789; S. Schwebel, 'The Influence of Bilateral Investment Treaties on Customary International Law', Proceedings of the American Society of International Law (2004) p. 27.

15 The so-called Hull rule, which called for prompt, adequate and effective compensation in the case of expropriation. This rule lost its customary law character due to several UN General Assembly resolutions in the 1960s and 1970s. See, e.g., Art. 2 of Charter of Economic Rights and Duties of States, GA Res. 3281 (XXIX), UN GAOR, 29th Sess., Supp. No. 31 (1974) 50. Nevertheless, this kind of compensation requirement is now to be found in the BITs. For details and an economic explanation for the apparently paradoxical behaviour of developing countries, see A.T. Guzman, 'Why LDCs Sign Treaties That Hurt Them: Explaining the Popularity of Bilateral Treaties', 38 Virginia Journal of International Law (1998) p. 639.

16 NAFTA, Chapter 11. Others are the Colonia Protocol of 1994 as annexed to the Mercado Común del Sur (MERCOSUR) Agreement of 1991, which was not ratified by any Member State of MERCOSUR, and the Framework Agreement on the ASEAN Investment Area (1998, amended 2001). The present article focuses only on BITs, but a similar reasoning applies to 
Most BITs and investment chapters in trade agreements usually have similar substantive provisions. ${ }^{17}$ They include the definition of the scope of application, that is to say, a definition of what constitutes an investment and who counts as a foreign investor. The definition of investment tends to be asset-based ${ }^{18}$ and is thus very broad. Asset-based definitions usually include all tangible and intangible assets, debt, contractual claims and intellectual property rights, including, for example, promissory notes or bank loans. This broad definition thus differs from the classical definition of FDI, which usually requires a long-term investment controlled by a foreigner who assumes a certain risk. The definition of 'investor' is also broad. Whereas for natural persons the nationality requirement is usually uncontested, determining the nationality of a legal person might be more difficult, as it can be defined by its place of incorporation, by its seat or by the control of the owners. BITs vary in their definitions and may use these requirements cumulatively. ${ }^{19}$ The rights of minority investors are usually included in the protection of BITs independently of the rights of the company itself. ${ }^{20}$

In addition, BITs contain general standards of treatment. They provide protection against direct and indirect (also 'creeping' or 'tantamount to') expropriation, ${ }^{21}$

those trade agreements. The reasoning might not be exactly the same, as the trade agreements link issues and thereby generate different incentives and participation constraints. See section 4 of this article.

17 For an overview of BITs, see R. Dolzer and M. Stevens, Bilateral Investment Treaties (The Hague, Nijhoff 1995).

18 For an overview of the definitions, see UNCTAD, UNCTAD Series on Issues in International Investment Agreements. Scope and Definition (2003), available at: <http://www.unctad. org/Templates/webflyer.asp?docid=189\&intItemID=1772\&lang=1>. On the notion of investment, see also N. Rubins, 'The Notion of "Investment" in International Investment Arbitration', in N. Horn, ed., Arbitrating Foreign Investment Disputes (The Hague, Kluwer 2004) p. 283.

19 Cf., R. Wisner and N. Gallus, 'Nationality Requirements in Investor-State Arbitration', 5 Journal of World Investment and Trade (2004) p. 927; K.E. Lyons, 'Piercing the Corporate Veil in the International Arena', 33 Syracuse J. Int'l L. \& Com. (2006) p. 523; P. Acconci, 'Determining the Internationally Relevant Link between a State and a Corporate Investor', 5 Journal of World Investment and Trade (2004) p. 139.

20 This is now established case law, see, e.g., GAMI Investments, Inc. v. Mexico, NAFTA by UNCITRAL Rules (15 November 2004), at paras. 26-42, in which the investor had 14.18 per cent; as well as CMS Gas Transmission Company v. Republic of Argentina, ICSID Case No. ARB/01/8, decision on jurisdiction (17 July 2003). For an overview, see S.A. Alexandrov, "The "Baby Boom" of Treaty-Based Arbitrations and the Jurisdiction of ICSID Tribunals: Shareholders as "Investors" and Jurisdiction Ratione Temporis', 4 The Law and Practice of International Courts and Tribunals (2005) p. 19.

21 Cf., B. Kunoy, 'Developments in Indirect Expropriation Case Law in ICSID Transnational Arbitration', 6 Journal of World Investment and Trade (2005) p. 467; C. Yannaca-Small, 'Indirect Expropriation' and the 'Right to Regulate' in International Investment Law, OECD Working Papers in International Investment No. 2004/4 (2004); R. Dolzer, 'Indirect Expropriations: New Developments?', 11 New York University Environmental Law Journal (2002) p. 64; V. Been and J.C. Beauvais, 'The Global Fifth Amendment? NAFTA's Investment Protections and the Misguided Quest for an International "Regulatory Takings" Doctrine', 78 New York 
require fair and equitable treatment ${ }^{22}$ of the investor, provide for national treatment and often contain a most-favoured-nation clause (MFN). They also might contain a so-called 'umbrella clause', which is a general promise to honour the obligations that the States entered into with the foreign investor, which are usually contractual agreements, such as licences or concession agreements. ${ }^{23}$ The umbrella clause may elevate contractual claims to international law claims and is therefore quite contested.

Last but not least, almost all treaties provide for international dispute settlement in which States waive their immunity from suit. The establishment of a private course of action with the possibility of obtaining damages for an international wrong transforms the context of international economic law by changing the incentive structure of the actors involved. The system is unique in PIL in that it gives investors ius standi to take disputes to international tribunals directly, mostly without exhaustion of local remedies. ${ }^{24}$ These international dispute settlement forums allow for the circumvention of national courts, which may

University Law Review (2003) p. 30; M. Brunetti, 'Indirect Expropriation in International Law', 5 International Law FORUM du droit international (2003) p. 150; R. Dolzer and F. Bloch, 'Indirect Expropriation: Conceptual Realignments?', 5 International Law FORUM du droit international (2003) p. 155; L.Y. Fortier and S.L. Drymer, 'Indirect Expropriation in the Law of International Investment: I Know It When I See It, or Caveat Investor', 19 ICSID Review (2004) p. 293; A.P. Newcombe, 'The Boundaries of Regulatory Expropriation in International Law', 20 ICSID Review (2005) p. 1.

22 Cf., C. Schreuer, 'Fair and Equitable Treatment in Arbitral Practice', 6 Journal of World Investment and Trade (2005) p. 357; S. Vasciannie, 'The Fair and Equitable Treatment Standard in International Investment Law and Practice', 70 BYIL (2000) p. 99; C. YannacaSmall, Fair and Equitable Treatment Standard in International Investment Law, OECD Working Papers in International Investment No. 2004/3 (2004); B. Choudhury, 'Evolution or Devolution? Defining Fair and Equitable Treatment in International Investment Law', 6 Journal of World Investment and Trade (2005) p. 297; R. Dolzer, 'Fair and Equitable Treatment: A Key Standard in Investment Treaties', 39 International Lawyer (2005) p. 87; S. Schill, 'Fair and Equitable Treatment under Investment Treaties as an Embodiment of the Rule of Law', 3 Transnational Dispute Management (2006) (online journal).

23 See S.A. Alexandrov, 'Breaches of Contract and Breaches of Treaty - The Jurisdiction of Treaty-Based Arbitration Tribunals to Decide Breach of Contract Claims in SGS v Pakistan and SGS v Philippines', 5 Journal of World Investment and Trade (2004) p. 555; C. Schreuer, 'Travelling the BIT Route - Of Waiting Periods, Umbrella Clauses and Forks in the Road', 5 Journal of World Investment and Trade (2004) p. 231; A.C. Sinclair, 'The Origins of the Umbrella Clause in the International Law of Investment Protection', 20 Arbitration International (2004) p. 411; T. Wälde, 'The "Umbrella" Clause in Investment Arbitration: A Comment on Original Intentions and Recent Cases', 6 Journal of World Investment and Trade (2005) p. 183; B. Kunoy, 'Singing in the Rain: Developments in the Interpretation of Umbrella Clauses', 7 Journal of World Investment and Trade (2006) p. 275.

24 Most BITs have some kind of waiting period for negotiation and require a very short period of time in which national courts need to decide (e.g., three or six months). This makes the latter requirement inapplicable de facto as court procedures usually take much longer than that, even in developed countries. 
either be dependent on government and/or might show a home bias or have excessively long adjudication periods. International investment law acquires immense force through this provision, as private (legal) persons are much more likely to take up their own cases. Under the former system, governments had discretion whether they wanted to grant diplomatic protection to their nationals (as is the case under WTO). That weakened investor protection, as States follow their own (diplomatic and political) calculations and might have well-considered reasons why not to take a case to an international court or tribunal even if their own nationals are concerned.

The principal forum chosen for investment arbitration is the International Centre for Settlement of Investment Disputes (ICSID), ${ }^{25}$ but arbitration also takes place under other rules, for example the UNCITRAL or ICC rules. The ICSID Convention was created in 1965 under World Bank auspices with the goal of fostering private capital flows to developing countries. Whereas there is no uniform text of international investment protection and no sitting judicial body, as in the case of the Appellate Body of the WTO, there is nevertheless a corpus of fairly similar substantive provisions and an international arbitration mechanism for investment, even though the composition of the tribunals varies from case to case and the interpretations of the tribunals (of similar and even equal clauses) may also vary. Many of the indeterminate and vague legal terms found in BITs have only recently been clarified by the decisions of international investment tribunals, although many of the interpretations are highly disputed, for example the jurisdictional question on the nationality of investors. Similarly, the meaning of indirect expropriation and what constitutes a violation of the fair and equitable treatment standard, the 'umbrella clause' or the MFN clause are highly contested, thereby creating legal insecurity for investors and States.

\section{THE SUCCESS OF INTERNATIONAL INVESTMENT LAW}

As alluded to before, the success of international investment law during the past fifteen years has been phenomenal. ${ }^{26}$ Not only have we seen a proliferation of BITs, but the system is also used by the relevant actors, that is to say, the States

25 Based on the Convention on the Settlement of Investment Disputes between States and the Nationals of Other States (ICSID Convention), 18 March 1965, 575 UNTS p. 159. For an overview of ICSID arbitration, including its advantages and disadvantages, see L. Reed, et al., Guide to ICSID Arbitration (The Hague, Kluwer 2004); as well as C. Schreuer, The ICSID Convention: A Commentary on the Convention on the Settlement of Investment Disputes Between States and Nationals of Other States (Cambridge, Cambridge University Press 2001).

${ }^{26}$ For a similar view, see B. Simmons, et al., Competing for Capital: The Diffusion of Bilateral Investment Treaties, 1960-2000, U. of St. Gallen Law \& Economics Working Paper No. 2007-21 (2007) and University of Illinois Law Review (2008, forthcoming). 
and the investors that make ever more use of international arbitration by relying on the provisions of BITs. Even though around 2,500 BITs have so far been concluded, though not all have been ratified, one would need 11,175 BITs (based on the 150 WTO Member States) in order to achieve a worldwide protection of investments that is similar to the inclusiveness of WTO. Whereas the first BITs were concluded between developed and developing countries, an increasing number of BITs and FTAs are now concluded between developing countries. ${ }^{27}$ Nevertheless, one can note a relative decline in the conclusion of BITs, with a peak in the middle of the 1990s. Although the number of FTAs is surging, and some of them contain investment chapters, this does not offset the relative decline found in the conclusion of BITs. ${ }^{28}$ The decline does not seem to be attributable to saturation, as investment flows are not confined to just a few countries. If BITs are to be seen as a potential marketing instrument by States, this marketing should reach all possible investors (and therefore countries). This decline has occurred simultaneously with a surge in international arbitration based on BITs during the last fifteen years. Known investment treaty arbitrations surged from almost zero in 1994 to almost 250 in 2006, most of the cases being conducted under ICSID..$^{29}$ Thus, whereas the conclusion of BITs peaked in the mid-1990s and has since then been in relative decline, disputes arising out of these BITs are on a continuous surge.

But that is only one way to look at success, of course. The other one is the question whether BITs really do foster foreign direct investment. If they do not, there would be no reason for States to trade off (regulatory) sovereignty against credibility and investment. In contract theory terms, there would be no positive pay-off for States if BITs did not foster investment. The empirical evidence has been inconclusive, though it now tilts slightly towards finding a positive relationship between BITs and FDI. Whereas Hallward-Driemeier finds no significant

27 UNCTAD, supra n. 5.

28 UNCTAD, supra n. 5, compare Figures I.10 and I. 14 and p. 28. Until 2006, a total of less than 250 international treaties with investment protection that were not BITs, such as FTAs, had been concluded. Between 2001 and 2005, around 100 such treaties were concluded. See also UNCTAD, 'Investment Provisions in Economic Integration Agreements' (Geneva/New York, UNCTAD 2006).

29 See UNCTAD, Latest Developments in Investor-State Dispute Settlement, IIA MONITOR No. 4 (Geneva/New York, UNCTAD 2006) p. 2. The ICISD websites registers 133 concluded cases (not all of them concluded by arbitration) and 116 pending cases as of 8 September 2007, see: <http://www.worldbank.org/icsid/cases/cases.htm>. Not all arbitrations are known, for example, if they are conducted under UNCITRAL. At least seventy governments - forty-four of them in the developing world, fourteen in developed countries and twelve in Southeast Europe and the Commonwealth of Independent States - have faced investment treaty arbitration. Argentina, Mexico, the United States and the Czech Republic have found themselves in the role of the defendant most often. 
effect of BITs on FDI, ${ }^{30}$ Tobin and Rose-Ackerman find that the relationship between FDI and BITs is weak with a slightly more positive effect at high levels of country risk, ${ }^{31}$ and in a newer study confirm a positive relationship. ${ }^{32}$ Salacuse and Sullivan find that stricter BITs increase FDI, whereas less strict BITs have no significant effect. They compare US BITs with BITs from other OECD countries, which are indeed less strict for a variety of reasons, for example, admission of investment as well as the prohibition of performance requirements..$^{33}$ The newest and most extensive and reliable study was carried out by Neumayer and Spees. They find an overall positive and significant effect of BITs on FDI. ${ }^{34}$ In short, BITs matter, at least on the margin, and do what they are supposed to do, namely fostering foreign direct investment, all other things being equal. Of course, that does not mean that other factors such as market size, market potential and natural resources may not be more important as a decision factor for enterprises. ${ }^{35}$

\section{THE ECONOMIC LOGIC OF BITS}

In order to understand the underlying logic of BITs, this article draws on economic contract theory, assuming that States (as well as enterprises) act rationally when concluding treaties. Traditionally, the legal analysis of contracts takes an ex post perspective, that is to say, it focuses on rights and obligations after there has been an alleged breach as well as on the recovery of losses for the injured party. Contract theory shifts the focus to the ex ante decision to why and under what circumstances parties enter into the contract in the first place, thus acknowledging the consensual approach as well as the participation constraints on parties.

${ }_{30}$ M. Hallward-Driemeier, Do Bilateral Investment Treaties Attract FDI?: Only a Bit... and They Could Bite, World Bank Policy Research Working Paper No. WPS 312 (2003).

31 J. Tobin and S. Rose-Ackerman, Foreign Direct Investment and the Business Environment in Developing Countries: The Impact of Bilateral Investment Treaties, Yale Law \& Economics Research Paper No. 293 (2005).

32 J. Tobin and S. Rose-Ackerman, 'When BITs Have Some Bite: The Political-Economic Environment for Bilateral Investment Treaties' (2006), available at: $<$ http://www.law.yale.edu/ documents/pdf/When_BITs_Have_Some_Bite.doc $>$.

33 J.W. Salacuse and N.P. Sullivan, 'Do BITs Really Work? An Evaluation of Bilateral Investment Treaties and their Grand Bargain', 46 Harvard International Law Journal (2005) p. 67.

34 E. Neumayer and L. Spees, 'Do Bilateral Investment Treaties Increase Foreign Direct Investment to Developing Countries?', 33 World Development (2005) p. 1567, who have data from 119 countries and look at the period from 1970 to 2001. T. Büthe and H.V. Milner, The Politics of Foreign Direct Investment into Developing Countries: Increasing FDI through Policy Commitment Via Trade Agreements and Investment Treaties?, Working Paper (2005), available at: <http://polisci.ucsd.edu/calendar/ButheMilner_FDI_24mar05.pdf >, who also find a positive relationship.

35 Brazil, for example, has not ratified any BIT and is nevertheless the biggest recipient country of FDI in Latin America after Mexico. UNCTAD, supra n. 5. 
Contract theory is primarily an analytical approach for explaining why parties contract in the first place and why they write the contracts they do in light of what courts do. It also helps to answer questions of optimal contracting. Though contract theory was developed mainly for individual contracting and not for international law, it has now also been applied to international relations. ${ }^{36}$

Enforceable contracts are a mechanism for achieving compliance with cooperative goals that are supposed to benefit the collective interest (or joint surplus) of parties whose particular interests may diverge at a given time. In investment law, the structure is more complicated than in normal private law contracts because the concluding parties (States) give rights to third parties (investors). Nevertheless, contract theory also promises some insights into optimal contracting.

One general problem in contract theory is how to deal with uncertainty and incomplete contracting, as the future (including the behaviour of the other party) is unknown and unknowable. Contract theory analyses problems of adverse selection, moral hazard and verification. At the heart of those problems are information asymmetries between the parties: each party has information about itself (private information) that the other does not. This gives rise to adverse selection (i.e., high-quality parties might be driven out of the market) ${ }^{37}$ and moral hazard, as well as to the problem of verifying hidden actions to a third party (i.e., investment tribunals). ${ }^{38}$ Complete contracts that foresee every contingency are impossible to draft and even trying to come close to this creates high negotiating costs. That in turn gives rise to the impossibility to foresee and describe appropriately the contractual outcome for all states of the future world: 'Contracts will be incomplete in the sense that they will fail to discriminate between states of the world that optimally call for different obligation. ${ }^{39}$ Parties entering into contracts usually face a problem. The contract should be optimal from an ex ante perspective, that is to say, it should encourage the parties at the time of the conclusion of the contract to invest in the contractual relationship so as to maximise the anticipated joint benefits. At the same time, however, parties want to write a

${ }^{36}$ Scott and Stephan, supra n. 9. The following part draws heavily on their analysis, especially chapter 3 .

37 See, generally, G.A. Akerlof, 'The Market for Lemons: Quality Uncertainty and the Market Mechanism', 84 Quarterly Journal of Economics (1970) p. 488, who illustrates the problem with the market for used cars (lemons). The problem is caused by the adverse selection of low quality sellers. In investment law, this problem can be mitigated for 'lemon' investors by admission procedures, as practiced by Australia, for example.

38 Contract theorists distinguish between observable and verifiable information. The former can be observed by the two parties, but it may still be that the information is not verifiable in the sense that the observing party is unable to establish the fact sufficiently to convince a neutral third party, for example the investment tribunal, at reasonable cost. See for details Scott and Stephan, supra n. 9, at p. 71 et seq.

39 Scott and Stephan, supra n. 9, at p. 76. 
contract that is 'optimal ex post, that is, a contract that is still value maximizing after all future uncertainties have been resolved as of the time of performance. ${ }^{40}$ Those two partially conflicting goals create an inherent tension, as ex ante each party would like to ensure the commitment of the other, but subsequent events may render inflexible commitments inconsistent with the contractual objective of maximising the joint surplus. This problem becomes acute in long-term contracts such as BITs but also in State contracts, for example in natural resource or public utility concessions, which often have durations of more than twenty-five years, especially if covered by umbrella clauses. 'Unforeseen circumstances may cause the cost to one of the parties to complete a promised investment to exceed the value that the counterparty expected to generate from the contract. ${ }^{41}$ For host States, those costs may not only be economic but also political..$^{42}$

As is well acknowledged in contract theory, the advantage of writing a contract with 'hard' and precise terms is the ensurance of credible commitments. But unless the parties can 'fully and accurately anticipate the conditions that exist at the time of performance, a contract containing only "hard" terms will always turn out to be suboptimal once the future arrives. [...] In short: once conditions change, a contract with hard terms will lead to outcomes that are less desirable than those the parties would have agreed to had they known the uncertainties in advance. ${ }^{93}$ Anticipating this, the parties would then want flexibility to adjust the investment whenever future circumstances make the investment no longer profitable (for either side). More flexibility in turn leads to a weakening of the credibility of the parties. There is thus a trade-off in contracting with regard to the credibility of a commitment, on the one hand, and the desired ex post flexibility, on the other.

Parties might thus choose to express their obligations in more general terms and delegate the interpretation to third parties in order to account for the necessary ex post flexibility. The crucial criterion in contract theory is whether appropriate proxies for the contested circumstances can be specified ex ante or whether a disinterested third party can be trusted to make such a selection ex post with the benefit of the hindsight. Contract theory therefore distinguishes between precise and vague terms (or 'rules v. standards' or 'hard v. soft norms'), with standards delegating more discretion to courts and tribunals, though it might be that standards are reserved for self-judgment (e.g., essential security clauses in Art. XXI GATT) in cases where private information is very difficult to verify. Usually, a combination of both is found.

40 Scott and Stephan, supra n. 9, at p. 61.

41 Scott and Stephan, supra n. 9.

42 As, for example, in Argentina's economic and political crisis of 2000-2001 or the public unrest behind the case Aguas del Tunari v. Bolivia, ICSID Case No. ARB/02/3, decision on jurisdiction (21 October 2005).

43 Scott and Stephan, supra n. 9, at p. 77. 
Let us now turn to investment law more specifically. Undisputedly, countries, especially developing countries, have a strong incentive to attract FDI and compete for it. ${ }^{44}$ The fundamental problem for countries is to make the protection more credible. ${ }^{45}$ As the potential host State can promise ex ante to honour the property right of the investor, the State may renege on its promises ex post if there is no sanction. Firms cannot usually disinvest in full once they have placed a fixed investment, as those investments are usually relation-specific. There is thus a hold-up problem. Once one party, in investment law, the investor, has undertaken such an investment, it becomes vulnerable to exploitation if the other party, the host State, fails to reciprocate fully. States can take advantage of this in several ways, for example by increasing taxes (even though they might have promised a preferential tax regime to the investor), by changing the royalty division in case of natural resources extraction ${ }^{46}$ or by prohibiting the augmentation of prices in cases of privatised utilities ${ }^{47}$ The host State will do so if the net benefits of reneging on its promise are greater than the net benefits of complying with its promise. As firms anticipate a possible later expropriation or unfair treatment, they may refrain from investment, leading to the socially undesired result of less investment.

The solution to the problem is to make the commitment of the host State credible, and BITs do exactly that. States give a reciprocal promise to treat the nationals of the other State in a certain manner. BITs are international law treaties giving protection to private persons or firms, thus creating a de facto regime of State liability for regulation..$^{48}$ Investment protection thus becomes an instrument to attract scarce resources by reducing the risk of ex post opportunism on the part of host countries. BITs place host States under a credible threat if they renege on their international law promises (i.e., BITs) or their promises in national law State contracts (e.g., concession agreements) if there is an umbrella clause. The commitment is made especially forceful by third-party adjudication.

44 See Simmons, et al., supra n. 26; Guzman, supra n. 15.

45 This certainly applies to States that do not have strong property rights protection in national law, which in turn leads to the problem that their capacity may not be able to live up to the 'one size fits all' provisions of BITs. Furthermore, 'rule of law' States such as the United States have been defendants in many cases.

46 This is currently a serious problem for foreign oil companies in Venezuela.

47 For example, Aguas del Tunari v. Bolivia, ICSID Case No. ARB/02/3, decision on jurisdiction (21 October 2005) (water utility); CMS Gas Transmission Company v. Argentine Republic, ICSID Case No. ARB/01/8 (12 May 2005) (energy transport utility); and recently Compañiá de Aguas del Aconquija S.A. and Vivendi Universal v. Argentine Republic, ICSID Case No. ARB/97/3 (20 August 2007) (water utility).

48 For a similar reasoning in the NAFTA Chapter 11 context, see A. Afilalo, 'Constitutionalization through the Back Door: A European Perspective on NAFTA's Investment Chapter', 34 New York University Journal of International Law and Politics (2001) p. 1 at p. 6. 
By creating this system, the pay-off for the host States is changed through sanctions. Direct sanctions consist of damages that may be quite high for developing countries. ${ }^{49}$ ICSID decisions also have res iudicata effect ${ }^{50}$ in all 144 Member States of the Convention, which means that the decisions can be executed in those countries where the host State has property (e.g., bank accounts) unless sovereign immunity comes into play. This makes reneging on the decision of an ICSID tribunal more difficult than non-compliance with decisions under, for example, the New York Convention, ${ }^{51}$ where national courts can review the international arbitral award and set it aside, for example for public policy reasons. ICSID arbitration therefore offers a much more secure dispute resolution mechanism for investors than other venues. Just as forceful are the indirect sanctions of the reputational effect of being an unreliable host State. ${ }^{52}$ The reputational effect can come into play not only with an award against the host State and/or noncompliance with an award but also at an earlier stage, that is to say, when a case is published as pending on the ICSID website. At that stage, the host State may already lose its reputation and, thus, future investment. A bad (or good) reputation may be reversed by a new government that takes measures in order to seem more credible and attract investment (or reverses a favourable investment policy due to a change in government).

At first sight, economic logic tells us that BITs are an adequate mechanism for dealing with the commitment problem. Nevertheless, there is a downside to solving the commitment problem too strictly, namely an optimisation problem that I wish to outline here. The inefficiency caused by excessively inflexible contracting can also be found in investment law. In the case of PIL, Abbott and Snidal $^{53}$ identify two more variables in order to determine the 'hardness' of an international agreement: (1) obligation $(\mathrm{O})$ : how binding is the obligation?; (2) delegation (D): is there any central authority created for monitoring and adjudication?; and, lastly, the above-mentioned vagueness, that is to say, (3) precision (P): how precise is the obligation? International law is to be found on a continuum on a scale from 'soft' to 'hard' law. International investment law belongs in the

49 Even though Argentina is an extreme case, it can expect over USD 20 billion in damages from around thirty-five pending cases, amounting to an annual budget for compensation for the emergency measures it took during the economic crisis of 2000-2001.

50 The Member States recognise ICSID awards as national court decisions, that is to say, the awards have the formal imprimatur that they are binding and final, Art. 53(1) ICSID Convention.

51 UN Convention on the Recognition and Enforcement of Foreign Arbitral Awards (New York Convention), 10 June 1958, 330 UNTS p. 38, which presumes the validity of awards and mandates enforcement except for procedural grounds or public policy grounds.

52 For an economic theory of compliance based on reputational effects, see Guzman, supra n. 3. See also Scott and Stephan, supra n. 9, at p. 68.

53 K.W. Abbott and D. Snidal, 'Hard and Soft Law in International Governance', 54 International Organization (2000) p. 421. 
corner of 'hard law', due to the creation of enforceable rights of investors and third-party adjudication, thereby creating credible commitments, except for the precision of the terms of BITs. ${ }^{54}$

In international investment law, contractual uncertainty has many facets: the uncertainty of opportunistic behaviour of States or firms; the uncertainty of States' capacity to fulfil their international obligations through domestic regulatory policy ${ }^{55}$ the uncertainty of the development of world market prices for natural resources, the uncertainty of how governments react to citizens' reactions unfavourable to the investment in question; and so forth. ${ }^{56}$ Is a strict promise $e x$ ante the only solution? In practice, large parts of international law are phrased in 'soft' terms, allowing for adjustment to contingencies. ${ }^{57}$ In addition, BITs are drafted mostly in vague terms, thus delegating discretion to tribunals, though they are 'hard' law measured against the other criteria of Abbot and Snidal. This makes the interpretation of the tribunals crucial for the efficiency and ultimately the stability of the system. Contract theory assumes disinterested third-party adjudication; to my knowledge, no literature exists in contract theory on the question of potential conflicts of interest of courts or tribunals. It is, however, a known problem in investment arbitration. Some commentators diagnose a systemic problem of revolving doors between arbitrators and counsel. ${ }^{58}$ Furthermore, so-called 'issue conflicts' ${ }^{59}$ may arise if the same person is at the same time both an arbitrator and counsel for an investor when the interpretation of the same substantive norm is in question (albeit in different proceedings). Certainly, a problem has arisen due to the wide discretion of international tribunals and the diversity in their interpretation of BITs. This is aggravated because most BITs

${ }^{54}$ From a contract theory point of view, see also Scott and Stephan, supra n. 9, p. 148, who distinguish between formal and informal enforcement mechanisms. Formal enforcement entails the possibility of standing of private parties before an independent tribunal that has the authority to impose sanctions. Investment law falls into this category.

55 See Downs and Rocke, supra n. 9, at p. 105 et seq.

56 Downs and Rocke, supra n. 9, see a clear danger of a gambling for resurrection in case of war, for example. In investment law, the danger is rather that the costs felt by excessively strict BITs are shifted by governments to later governments (and generations), whereas the gains are reaped immediately.

57 Most generally, Art. 62 of the Vienna Convention on the Law of Treaties, 23 May 1969, 1155 UNTS p. 331.

58 T. Buergenthal, 'The Proliferation of Disputes, Dispute Settlement Procedures and Respect for the Rule of Law', 3 Transnational Dispute Settlement (2006) (online journal) p. 6: 'These revolving-door problems - counsel selecting an arbitrator who, the next time around when the arbitrator is counsel, selects the previous counsel as arbitrator - should be avoided. Manus manum lavat, in other words "you scratch my back and I'll scratch yours", does not advance the rule of law.' Arbitration Rule 6 of the new Arbitration rules of the ICSID Convention now indeed has stricter conflict of interest rules for arbitrators.

59 J. Levine, 'Dealing with Arbitrator "Issue Conflicts" in International Arbitration', 3 Transnational Dispute Management (2006) (online journal). 
were concluded before the surge in arbitral decisions. It was difficult for States to predict judicial outcomes of disputes with any degree of certainty and thus also difficult for them to know how 'hard' their commitment was. Whereas some tribunals have been on the 'flexibility' side by deferring to the regulatory policy decisions of host States giving them a bigger margin of appreciation, others tend to interpret treaties based on a narrowly understood object and purpose of BITs, that is to say, investor protection. Ex post, the latter thus turn out to be a contract with 'hard' terms, which has a greater tendency to be inefficient from an ex post perspective. This in turn gives rise to the peril of success.

5. THE PERIL OF SUCCESS

Thus, one possible problem for States in investment law is the cost of (unforeseen) strict promises. Thus, a peril arises: the participation constraints on States. ${ }^{60}$ Generally speaking, States will only participate in the system if the expected costs of constraining its (regulatory) sovereignty through BITs and State contracts will deliver expected (net) benefits. States may not like 'hard law' due to sovereignty costs, that is to say, costs that are created by the restriction of possible action. For example, certain regulatory measures cannot be taken or certain policies may not be allowed without due compensation (e.g., environmental measures, tax policy or certain economic or monetary policies). 'Hard' law can arise due to two facts: either the treaty is written as completely as possible, with strict promises by States, or it is written in vague terms and tribunals interpret the terms in a strict manner. Both of these possibilities are discussed below.

The obligation in the sense of Abbott and Snidal is high, if the ex ante explicit restriction of reaction possibilities to unforeseen circumstances is high (precise terms). Comparing investment law with trade law shows that there are usually no general exception clauses in BITs as there are in the WTO law (e.g., Art. XX GATT, Arts. XIV and XIVbis GATS or the Safeguards Agreement), although it is sometimes possible for a State to escape BIT obligations by taking measures for the "protection of its own essential security interests. ${ }^{61}$ Here, the force of the

60 This constraint is a notion of game theory, more specifically mechanism design. It is satisfied if a mechanism leaves all participants at least as well off as they would have been if they had not participated. Scott and Stephan, supra n. 9, at p. 28, somehow use the notion implicitly, drawing on classical contract theory, which uses as a crucial criterion of observable and verifiable conditions for the kind of enforcement chosen by States.

61 The US BITs are an exception in this respect. Like earlier treaties, the Model BIT 2004 contains such a clause in Art. 18: Essential Security: 'Nothing in this Treaty shall be construed: 1. to require a Party to furnish or allow access to any information the disclosure of which it determines to be contrary to its essential security interests; or 2. to preclude a Party from applying measures that it considers necessary for the fulfillment of its obligations with respect to the maintenance or restoration of international peace or security, or the protection of its own essential security interests.' A similar approach can be found in Art. 24 of the Energy Charter 
obligation depends largely on whether these escape clauses are self-judging or only subject to good faith scrutiny. ${ }^{62}$ This is usually denied by international tribunals, unless the clauses explicitly say so, even against the will of both State Parties to the relevant BIT, ${ }^{63}$ an interpretation that would need to justify why Article 31(3)(b) of the Vienna Convention on the Law of Treaties (VCLT) was not applied. The invocation of State necessity in a BIT and in customary international law ${ }^{64}$ by Argentina due to its economic crisis in 2000-2001 was not accepted by the majority of the tribunals ${ }^{65}$ thus obligating Argentina to pay compensation for the tariff freeze it had imposed on public utilities and its devaluation of its currency. ${ }^{66}$ The costs of the obligations may thus be quite high, as a country may no longer be free to react to external or internal economic or

Treaty, 17 December 1994, 33 ILM p. 381 (though it does not apply to direct or indirect expropriation).

${ }_{62}$ For a discussion of the case in the broader context of State necessity and investment protection, see A. van Aaken, 'Zwischen Scylla und Charybdis: Völkerrechtlicher Staatsnotstand und Internationaler Investitionsschutz', 105 Zeitschrift für vergleichende Rechtswissenschaft (2006) p. 544.

${ }^{63}$ The tribunal in CMS Gas Transmission Company v. Argentine Republic, ICSID Case No. ARB/01/8 (12 May 2005) rejected this provision in the first Argentine crisis case. Even though it confirmed the applicability in economic crisis cases, it denied protection to Argentina on the grounds that there was no economic emergency (in contrast to the national emergency law of Argentina). It also held, contrary to the expert opinion of Prof. Slaughter, that there were no limits to the control of the tribunal in relation to this clause, that is to say, the tribunal did not defer to the assessment of the Argentine government and only controlled for obvious misuse (good faith limits), as national constitutional courts would usually do. In its Application for Annulment and Request for Stay of Enforcement of the Arbitral Award of 8 September 2005, Argentina argued that the US State Department viewed such clauses as self-judging (para. 39). Thus, though both States involved argued for self-judgment, the tribunal did not agree. A similar reasoning was applied by the tribunal in $L G \& E$ Energy Corp., LG\&E Capital Corp. and LG\&E International Inc. v. Argentine Republic, ICSID Case No. ARB/02/1, decision on liability (3 October 2006). The tribunal also held that the escape clause was not self-judging and stated that the United States still held that these clauses were not self-judging when it concluded the BIT with Argentina and only later changed its position.

${ }_{64}^{64}$ As codified in Art. 25 of the ILC Draft on State Responsibility.

${ }_{65}$ CMS Gas Transmission Company v. Argentine Republic, ICSID Case No. ARB/01/8 (12 May 2005); and Enron Corporation, Ponderosa Assets L.P. v. Argentine Republic, ICSID Case No. ARB/01/3 (22 May 2007). The tribunal in $L G \& E$ Energy Corp., $L G \& E$ Capital Corp. and $L G \& E$ International Inc. v. Argentine Republic, ICSID Case No. ARB/02/1, decision on liability (3 October 2006) found that Argentina indeed was in a state of necessity for a period of seventeen months. Argentina's annulment application in the CMS case was unsuccessful in this respect, see Decision of the ad hoc Committee on the Application for Annulment of the Argentine Republic of 25 September 2007.

${ }_{66}$ National investors did not get any compensation as their path to ICSID is barred. In total, 3,783 petitions have been filed with the Inter-American Commission of Human Rights regarding the Corralito measures (freezing of individual bank accounts), but as yet there is no decision. 
political shocks and crises without paying compensation to foreign investors. This is presumably ex post inefficient.

Apart from these explicit escape clauses, there is another interpretational method of rendering investment law more flexible in the light of non-investment law in order to achieve harmonious interpretation between international legal obligations for States. Article 31(3)(c) VCLT allows for the consideration of other international treaties concluded between the parties. ${ }^{67}$ That is to say, international environmental treaties or human rights treaties may also be taken into account when determining the obligations of States, for example in the interpretation of indirect expropriation or fair and equitable treatment. In practice, however, this is not often done. ${ }^{68}$

Furthermore, States may not want to ratify BITs that restrict their sovereignty unpredictably. There is an informational problem for States as in time 1 host countries give promises that may lead to welfare losses in the future. Here, flexibility costs (a subset of sovereignty costs) arise, that is to say, States may not be able to act as they thought they could ex ante. Generally speaking, if precision is high and the promise is strict, then the flexibility costs, understood as sovereignty costs, may also be high. States may therefore prefer low precision ex ante, unless they feel that they can explicitly restrain certain protective norms without loss of credibility ${ }^{69}$ But if precision is low, a problem arises through delegation and progressive interpretation. ${ }^{70}$ If States thought of giving a promise $\mathrm{P}_{\mathrm{A}}$ in time 1 and find out in time 2 that they promised $\mathrm{P}_{\mathrm{B}}\left(\right.$ with $\left.\mathrm{P}_{\mathrm{B}}>\mathrm{P}_{\mathrm{A}}\right)$, they might, through a learning process, react in the light of the experiences. For example, countries may turn to less favourable promises or restrict the interpretational discretion of international tribunals if they think that the net benefit of credible commitment is turning negative. They might change the promise $\mathrm{P}_{\mathrm{A}}$ for the future by various means.

67 See, extensively, C. MacLachlan, 'The Principle of Systematic Integration and Art. 31(3)(c) of the Vienna Convention', 54 ICLQ (2005) p. 279, who describes that interpretational method as the 'master-key' of constructing the large building of international law (p. 280 et seq.).

68 For details, see A. van Aaken, 'Fragmentation of International Law: The Case of International Investment Law', Finnish Yearbook of International Law (2008, forthcoming).

69 As, for example, in the new US Model BIT 2004, which considerably restricts the interpretational discretion concerning indirect expropriation in Annex B: 'Except in rare circumstances, nondiscriminatory regulatory actions by a Party that are designed and applied to protect legitimate public welfare objectives, such as public health, safety, and the environment, do not constitute indirect expropriations.' This is presumably a reaction to the extensive interpretation of ICSID tribunals. The same holds for the investment part of the JapanPhilippines Economic Partnership Agreement, available at: <http://www.mofa.go.jp/region/ asia-paci/philippine/epa0609/main.pdf $>$, which includes several exceptions and safeguards concerning regulatory issues (see Art. 99 et seq.).

70 It is debatable whether some of the interpretations are even praeter legem interpretations. 
Thus, if precision is low, flexibility costs depend crucially on the interpretation by the tribunal. In practice, we find quite progressive interpretation by ICSID tribunals. ${ }^{71}$ In the view of some tribunals, BITs are instruments for the maximisation of investor protection. Accordingly, uncertainties as to how to resolve ambiguous treaty provisions should be resolved in favour of foreign investors. ${ }^{72}$ Lately, a few other arbitral tribunals or minority arbitrators have dismissed such an approach, calling instead for a more balanced interpretation that considers both the necessity to protect foreign investment and the State's sovereign responsibility to provide for 'an adapted and evolutionary framework for the development of economic activities' ${ }^{73}$ that gives a greater margin of appreciation to States. ${ }^{74}$ The United States, in a dispute concerning itself as a respondent, contended that 'a doctrine of restrictive interpretation should be applied in investor-State disputes. In other words, wherever there is any ambiguity in clauses granting jurisdiction not be.

71 Progressive interpretation could be a function of arbitrators' interests, but does not need

72 See, e.g., SGS Société Générale de Surveillance S.A. v. Republic of the Philippines, Case No. ARB/02/6 (29 January 2004) at para. 116: 'It is legitimate to resolve uncertainties in its interpretation so as to favour the protection of covered investments.'

73 Pan American Energy LLC and BP Argentina Exploration Company v. Argentine Republic, ICSID Case No. ARB/03/13, decision on preliminary objections (27 July 2006) at para. 99; and El Paso Energy International Company v. Argentine Republic, ICSID Case No. ARB/03/15, decision on jurisdiction (27 April 2006) at para. 66 et seq. and para 70: 'a balanced interpretation is needed, taking into account both State sovereignty and the State's responsibility to create an adapted and evolutionary framework for the development of economic activities, and the necessity to protect foreign investment and its continuing flow', thus rejecting a one-sided interpretation either in favour of foreign investors or in favour of host States. See also Noble Ventures, Inc. v. Romania, ICSID Case No. ARB/01/11 (12 October 2005) para. 52, concerning the teleological interpretation of an umbrella clause: 'The object and purpose rule also supports such an interpretation. While it is not permissible, as is too often done regarding BITs, to interpret clauses exclusively in favour of investors, here such an interpretation is justified.'

74 For example, S.D. Myers, Inc. v. Government of Canada, NAFTA by UNCITRAL Rules, 1st Partial Award (13 November 2000) paras. 261 and 263; Saluka Investments B.V. v. Czech Republic, Partial Award (17 March 2006) para. 304 et seq. 'This Tribunal would observe, however, that while it subscribes to the general thrust of these and similar statements [stability of the legal system of the host State - AvA], it may be that, if their terms were to be taken too literally, they would impose upon host States' obligations which would be inappropriate and unrealistic. Moreover, the scope of the Treaty's protection of foreign investment against unfair and inequitable treatment cannot exclusively be determined by foreign investors' subjective motivations and considerations. Their expectations, in order for them to be protected, must rise to the level of legitimacy and reasonableness in light of the circumstances. 305 . No investor may reasonably expect that the circumstances prevailing at the time the investment is made remain totally unchanged. In order to determine whether frustration of the foreign investor's expectations was justified and reasonable, the host State's legitimate right subsequently to regulate domestic matters in the public interest must be taken into consideration as well.' 
over disputes concerning States and private persons, such ambiguity is always to be resolved in favour of maintaining State sovereignty'. ${ }^{75}$

Indeterminate legal terms, for example 'fair and equitable treatment' or indirect expropriation, have often been interpreted progressively and in a strict manner when the 'legitimate expectations' of the investor were the crucial criterion in determining a breach. ${ }^{76}$

Furthermore, the definition of investor in BITs has been a contentious issue, as it determines who can get the protection of a BIT and to whom the State's promise was made. It may happen that the State faces an unexpected extension of the circle of promisees. Tokios Tokeles v. Ukraine ${ }^{77}$ was a dispute mounted under the Lithuania-Ukraine BIT, in which a group of Ukrainian investors had incorporated a legal entity in Lithuania and then used that entity to invest back into Ukraine in order to avail themselves of the protections promised to 'Lithuanian' investors by Ukraine under the BIT. The majority of the tribunal stated that the parties to a BIT were free to determine the criteria for nationality ${ }^{78}$ and set the definition of investor and foreign control of a local entity for the purposes of Article 25(2)(b) of the ICSID Convention. In a rare occurrence, the president of an ICSID arbitral tribunal, Prosper Weil, dissented from this decision on jurisdiction and signalled his concern for the 'integrity' of the ICSID system, as the interpretation of the majority would ultimately allow nationals to seek protection against their own State in international tribunals. That, in his opinion, would destabilise the system as such and go against international law principles. In Aguas del Tunari v. Bolivia, ${ }^{79}$ the investors migrated the holding company of Aguas del Tunari from the Cayman Islands to Luxembourg, whose shares were in turn held by a newly established firm in the Netherlands, thereby using the Netherlands-Bolivian BIT in order to go to ICSID. ${ }^{80}$ The definition of the nationality of corporate entities is a long-known problem but is becoming ever more pressing in a more globalised world where firms have increasingly complicatedly structures. It is unclear whether tribunals accept or pierce the corporate veil. When they choose the latter, it is also unclear whether they stop at the first

75 Methanex Corp. v. United States of America, NAFTA by UNCITRAL Rules, 1st Partial Award (7 August 2002) para. 103.

76 For a discussion, see R. Dolzer, 'Indirect Expropriations: New Developments?', $11 \mathrm{New}$ York University Environmental Law Journal (2002) p. 64.

77 ICSID Case No. ARB/02/18, decision on jurisdiction (29 April 2004). Depending on the treaty provision on the nationality of a firm, this now allows a de facto coverage of domestic investors operating through a holding company incorporated in the other State party.

78 Ibid., at para. 24.

79 Aguas del Tunari v. Bolivia, ICSID Case No. ARB/02/3, decision on jurisdiction (21 October 2005).

80 The ultimate majority owner was Bechtel, a US-American firm. 
level of shareholders, whether they look at the ultimate beneficiaries or whether they stop somewhere in between. ${ }^{81}$

A further unforeseen circumstance is the interpretation of the most-favourednation (MFN) clause, a multilateralisation devise par excellence that allows investors to get the protection of any other BIT concluded by the host State if it is more favourable than the BIT between the host State and an investor's home State. Whereas MFN clauses were originally only supposed to apply to substantive issues, the ICSID tribunal decided in Maffezzini v. Spain ${ }^{82}$ that the MFN clause also applies to procedural provisions ${ }^{83}$ The possibility of BIT-shopping by enterprises is therefore a problem from the viewpoint of States. Investors may play opportunistically in cases of forum shopping possibilities (MFN and the nationality of investors). From the viewpoint of foreign investors, it is in each individual firm's interest to play the BIT game opportunistically and try to go to ICSID in order to get a progressive interpretation of the BIT. For a group of investors, however, this may result in States making fewer 'hard law' promises, leading to less protection for firms. Investors therefore find themselves in a classical prisoners' dilemma game.

A further contentious issue is the so-called 'umbrella clause'. The interpretation debate over the concrete meaning of this - potentially powerful - provision found in many BITs has high stakes, as it decides on the applicable law as well as the forum of the dispute (national v. international). A broad interpretation of such clauses opens up the possibility to sue States under international law whenever a contractual commitment or undertaking has been breached by a State or a State agency without it being necessary to prove some other breach of the relevant

81 See P. Acconci, 'Determining the Internationally Relevant Link between a State and a Corporate Investor', 5 Journal of World Investment and Trade (2004) p. 139; Wisner and Gallus, supra n. 19.

82 Emilio Maffezzini v. Kingdom of Spain, ICSID Case No. ARB/97/7, decision on jurisdiction (25 January 2000).

83 The Maffezzini reasoning was recently followed by Suez, Sociedad General de Aguas de Barcelona S.A., and InterAguas Servicios Integrales del Agua S.A. v. Argentina, ICSID Case No. ARB/03/17, decision on jurisdiction (16 May 2006), at para. 52 et seq. It distinguished its reading from Plama Consortium Limited v. Republic of Bulgaria, ICSID Case No. ARB/03/24, decision on jurisdiction (8 February 2005). For a more restrictive reasoning, see also SaliniCostruttori S.p.A. and Italstrade S.p.A. v. Jordan, ICSID Case No. ARB/02/13, decision on jurisdiction (9 November 2004); Siemens v. Argentina, ICSID Case No. ARB/02/8, decision on jurisdiction (3 August 2004). Also, in a recently decided case, Telenor Mobile Communications $A S$ v. Republic of Hungary, ICSID Case No. ARB/04/15, decision on jurisdiction (13 September 2006) para. 95, the tribunal declined to grant the protection of the MFN clause to procedural issues, noting: 'In these circumstances, to invoke the MFN clause to embrace the method of dispute resolution is to subvert the intention of the parties to the basic treaty, who have made it clear that this is not what they wish'. In the same vein, see Berschader \& Berschader v. The Russian Federation, Arbitration Institute of the Stockholm Chamber of Commerce; UNCTAD, supra n. 29. 
treaty. Under this interpretation, the clause subsumes all contractual breaches under the umbrella of the treaty, thus obviating the need for foreign investors to rely on the dispute settlement provisions contained in the relevant State contract (e.g., local courts or other forms of arbitration). Nevertheless, tribunals have openly clashed over the meaning to be ascribed to such treaty clauses and the extent to which they may permit foreign investors to dispense with the dispute settlement provisions spelled out in contracts in favour of pursuing international arbitration under a treaty. ${ }^{84}$

The list could be continued, but the above suffices to demonstrate why States may react against this development. States may stay out of the game altogether by not signing or ratifying BITs. Indeed, we have seen a relative decline in the conclusion of BITs that is not offset by the conclusion of investment chapters in trade agreements. For example, the United States and the Southern African Customs Union (SACU) were negotiating a free trade agreement but broke off talks because SACU did not want to include a US proposal on investment liberalisation and protection provisions in the proposed free trade agreement. ${ }^{85}$ States may also restrict (in new BITs) the interpretational supremacy of international tribunals by including a general saving clause regarding interpretation. Some BITs and FTAs contain provisions that retain the ultimate competence for interpretation for States, for example NAFTA. ${ }^{86}$ The NAFTA Free Trade Commission issued a binding statement in 2001 concerning the interpretation of fair and equitable treatment. ${ }^{87}$ It held that this provision only amounts to minimum standards of treatment and that it does not contain any transparency requirements for States, thereby cutting back the progressive interpretation of international arbitral tribunals. Very few BITs or FTAs retain this binding interpretational competence for States, ${ }^{88}$ which means that this

${ }^{84}$ The El Paso ruling, supra n. 73, is very instructive in this regard.

85 Investment Treaty News, 27 April 2006, published by the International Institute for Sustainable Development (<http://www.iisd.org/investment/itn>).

86 Under WTO law, the same holds true: Art. IX(2) WTO Agreement reserves the ultimate interpretational authority to a three-fourths majority of Member States.

${ }^{87}$ See 'Free Trade Commission Clarifications Related to NAFTA Chapter 11', 31 July 2001, available at: <http://www.ustr.gov/regions/whemisphere/nafta-chapter11.html >. The NAFTA member governments have reacted forcefully to their increasing liability under Chapter Eleven in a number of ways. On two occasions, they made joint policy statements to the effect that Chapter Eleven could limit investors' ability to bring claims. The United States has taken further steps in legislation and trade negotiations to ensure that the developments in some Chapter Eleven cases do not become institutionalised in future FTAs between the United States and other countries. Art. 91 of the Japan-Philippines Economic Partnership Agreement, available at: <http://www.mofa.go.jp/region/asia-paci/philippine/epa0609/main.pdf $>$, now repeats the NAFTA Free Trade Commission's remarks with regard to the relationship between 'fair and equitable treatment' and the international minimum standard, just like the new US Model BIT 2004.

88 While the US model BIT does, the European BITs generally do not. 
ultimate restriction on international tribunals does not work everywhere. ${ }^{89}$ Furthermore, of course, all States parties to the treaty have to agree on a common interpretation of a treaty norm. Nevertheless, this is a less costly and more subtle device than treaty renegotiation, as it allows for learning processes through a kind of functional renegotiation with low transactions costs and simultaneously mitigates the delegation problem of the States parties as arbitrators may anticipate the States' reactions.

States might also water down the substantive protection of foreign investors' rights when renegotiating BITs (or when concluding new BITs) by clarifying the meaning of the substantive provisions in a restrictive manner or by leaving some of the provisions out altogether. This reduces delegation to third parties by restricting progressive interpretation by means of the further specification of the interpretation of the protective norms in the next round of BIT negotiations (as the United States has done in its new Model BIT 2004). In this context, States write more complete contracts to clarify indeterminate legal terms, for example by stating that certain environmental or public security measures do not amount to indirect expropriation..$^{90}$ States may also water down the protection of investors by attenuating their rights from the beginning. For example, the 2005 economic cooperation agreement between India and Singapore left out the highly contentious provisions on fair and equitable treatment and the MFN clause. Of course, this means much less protection than usual in BITs. The newly negotiated trade and investment pact between Japan and the Philippines and the US-Australian free trade agreement all have usual substantive protective provisions but leave out the State's ex ante consent to an investor-State arbitration mechanism. ${ }^{91}$ In this context, the problem of CIL also arises. As alluded to above, CIL protection is in principle insufficient in terms of its substantive provisions and even less clear in its contours than the indeterminate legal terms found in the BITs. ${ }^{92}$ One should note, however, that, if CIL can be established for substantive provisions, it can be much more forceful than treaty law - as long as there is international jurisdiction in the case concerned - because CIL does not provide an opt-out option in the

89 Generally, it would be worthwhile to conduct research on the question how such a provision may change the behaviour of international tribunals or courts, depending on the number of treaty parties and majority requirements for changing the treaty.

90 See, e.g., the new US Model BIT 2004, which contains interpretation rules for tribunals concerning the most contentious terms.

91 See Art. 107 of the Japan-Philippines Economic Partnership Agreement. See the USAustralian FTA of 18 May 2004, available at: <http://www.ustr.gov/assets/Trade_Agreements/ Bilateral/Australia_FTA/Final_Text/asset_upload_file148_5168.pdf $>$.

92 On the difference between incentives under CIL and treaty law, see G. Norman and J.P. Trachtman, 'The Customary International Law Game', 99 American Journal of International Law (2005) p. 541, as a response to J.L. Goldsmith and E.A. Posner, 'A Theory of Customary International Law', 66 University of Chicago Law Review (1999) p. 1113. See also supra n. 14. 
long run as treaties do. ${ }^{93}$ Every State is bound by CIL, unless it has been a persistent objector. Thus, the participation constraints on States are weakened. States may therefore only restrict progressive interpretation by tribunals of the question of what constitutes CIL by drafting the contract more completely as the United States has done. ${ }^{94}$

Another way of restricting the scope of the treaties is by attaching reservations in certain sectors by means of a negative or positive list approach. This is lauded by UNCTAD as a key technique for balancing flexibility and the regulatory autonomy of national authorities with their international commitments. ${ }^{95}$ Reservations usually restrict the protective scope of the treaty to certain industries, which makes them a very blunt instrument. This is illustrated by the false positive/false negative (type I and type II error) distinction. Generally speaking, legal errors can be divided into two categories: type I errors, or false positives, in which meritless suits are allowed to be commenced, and type II errors, or false negatives, which keep legitimate claims out of court. Reservations tend to produce many false negatives, because there is no protection whatsoever for the excluded sectors. A more restrictive and flexible interpretation, taking account, for example, of uncertainty and sensitivities in highly politicised and problematic sectors such as natural resources and public utilities, might be a better way to reduces the abovementioned errors.

States may also choose non-compliance, even though that may be more costly for reputational reasons. In this case, a State will calculate whether compliance is more costly that losing foreign investment in the short run. For example, Argentina announced that it would not honour the ICSID awards in connection with the Argentine crisis of 2000-2001,96 although that statement was revoked for the decision on the staying of the CMS award. ${ }^{97}$ There are several (legal) ways to avoid being obliged to accept the execution of an ICSID award. ${ }^{98}$

Last but not least, States may decide to exit the treaties by not prolonging them. Ecuador was the first country to publicly announce that it may withdraw

93 For an overview of the definition and different understandings of CIL, see R. Bernhardt, 'Customary International Law', in R. Bernhardt, ed., EPIL (The Hague, Elsevier 1992) p. 898 at p. 902 et seq.; A.E. Roberts, 'Traditional and Modern Approaches to Customary International Law', 95 American Journal of International Law (2001) p. 757.

94 The new US Model BIT 2004 therefore states clearly in Annex A what is to be understood by CIL in investment protection.

95 UNCTAD, Preserving Flexibility in IIAs: The Use of Reservations (Geneva/New York, UNCTAD 2006).

96 See O.J. Marzorati, 'Argentina Opting Out?', 2 Transnational Dispute Management (2005) (online journal).

97 Decision on Argentine Republic's Request for a Continued Stay of Enforcement of the Award in CMS v. Argentina (1 September 2006).

98 E. Baldwin, et al., 'Limits to Enforcement of ICSID Awards', 23 Journal of International Arbitration (2006) p. 1. 
from its BITs, ${ }^{99}$ and Bolivia recently withdrew from the ICSID Convention. ${ }^{100}$ Exiting a treaty may be costly, as it has a reputational effect. ${ }^{101}$ Most BITs are concluded for a certain period of time (e.g., thirty years with an extension of the protection for an additional period, say, another ten years) but may be prolonged.

These arguments do not only apply to developing countries. Capital increasingly flows from transition or developing countries such as China, India and Brazil to the OECD countries (or other developing countries). ${ }^{102}$ It seems that only the United States has gone through a learning process with NAFTA, appearing as the defendant State in many cases ${ }^{103}$ and changing its new Model BIT accordingly in 2004 by making it more precise, giving less leeway to arbitral tribunals. ${ }^{104}$ Until now, Western European States have been largely spared from appearing as defendants in investor-State disputes (with the exception of the European transition countries ${ }^{105}$ ). That might change soon under the Energy Charter Treaty, which also provides for investor-State dispute settlement, energy policy being a highly contested field. It might well be that those countries will become more cautious in negotiating BITs that restrict their sovereignty excessively once they realise that the reciprocity in those treaties exists not only de iure but also de facto.

It is no coincidence that minority opinions in arbitral awards issue warnings about destroying the system if interpretation is stretched too far. Overprotection

99 S.D. Franck, 'Occidental Exploration \& Production Co. v. Republic of Ecuador', 99 American Journal of International Law (2005) p. 675; Investment Treaty News of 9 May 2007 concerning the termination of the US-Ecuador BIT.

100 Bolivia submitted its notice of withdrawal from the ICSID Convention on 2 May 2007. In accordance with Art. 71 of the Convention, the denunciation will take effect six months after the receipt of Bolivia's notice, that is to say, on 3 November 2007. That does not mean, however, that cases cannot be brought against Bolivia before ICSID under the Additional Facility Rules. Furthermore, as BITs have post-termination protection, the cases under dispute now might still be arbitrated under those BITs.

101 For an encompassing analysis, see L.R. Helfer, 'Exiting Treaties', 91 Virginia Law Review (2005) p. 1579.

102 UNCTAD, supra n. 5

103 Indeed, after Argentina and Mexico, the United States and the Czech Republic have the third highest number of claims filed against them with eleven each, see UNCTAD, supra n. 29, p. 2 et seq.

104 G. Gagné and J.-F. Morin, 'The Evolving American Policy on Investment Protection: Evidence from Recent FTAs and the 2004 Model BIT', 9 Journal of International Economic Law (2006) p. 357, who attribute, for example, the exclusion of an investor-to-State dispute mechanism in the US-Australian FTA to the US experience of complaints by Canadian investors under NAFTA, that is to say, investors from an equally developed country. For a similar hypothesis concerning the learning process that the United States has undergone due to Chapter 11 of NAFTA, see D.A. Gantz, Settlement of Disputes Under the Central AmericaUnited States-Dominican Republic Free Trade Agreement, Arizona Legal Studies Discussion Paper No. 07-01 (2007), available at: <http://ssrn.com/abstract=956134>.

105 Germany, Spain, Portugal, the United Kingdom and France were or are defendants in at least one well-known investment treaty case. See UNCTAD, supra n. 29, p. 12 et seq. 
by excessively strict commitments ex ante or progressive protection ex post may lead to reactions from States that will weaken international investment protection in the long run, ${ }^{106}$ which is a normatively undesirable outcome.

6. CONCLUSION AND OUTLOOK

One example of effective PIL is the case of international investment protection. But this effectiveness comes with perils, namely that States might wish to weaken the system in order not to incur excessively high sovereignty costs. We therefore face a dilemma. International investment law may become too successful from the viewpoint of States, which may lead to less protection of investors in the long run. The point of optimality between commitment costs and benefits of FDI still needs to be found.

States' participation constraints come into play only if the net benefit of giving credible commitments to investors is equal to or below zero (ex ante or ex post). In addition, it may well be the case that certain host countries that are competing with other countries for scarce capital cannot afford to lower the standards of protection. But it would be short-sighted to rely on this. There might be circumstances in which we come close to situations in which States prefer to opt out, for example certain Latin American countries that, within the tradition of the Calvo doctrine, would return to an old attitude towards FDI. But there are also more subtle means of restricting investor protection. Therefore, it is useful to think of other less costly protection instruments for States, for example insurance regimes that reduce sovereignty costs. It is also useful to consider BITs that either retain the interpretational supremacy of the States parties or are drafted in more detail. This also needs to be considered when the BITs are renegotiated. It would also be desirable to have a more balanced approach to treaty interpretation. Even if BITs and ICSID are designed to foster FDI by protection, the ultimate telos of those laws is the development of countries. ${ }^{107}$ This is also clearly indicated by the

106 For an analysis of the trade-off between participation, on the one hand, and the strictness of a treaty through nonconsensual international lawmaking, on the other, see L.R. Helfer, 'Participation, Compliance, and Nonconsensual International Lawmaking', Illinois Law Review (2008, forthcoming).

107 See, e.g., CME Czech Republic B.V. v. Czech Republic, UNCITRAL, Final Award, separate opinion of Ian Brownlie (14 March 2003); and Amco Asia Corporation and others v. Republic of Indonesia, ICSID Case No. ARB/81/1, decision on jurisdiction (20 November 1984) in: 23 ILM 351 (1984) p. 369 (para. 23): 'To protect investment is to protect the general interest of development and of developing countries.' On the ICSID Convention, see Schreuer, supra n. 25, Preamble, para. 11. The ICSID Convention's 'primary aim is the promotion of economic development'. For a similar view, see Amco v. Indonesia, at para. 493: 'Thus, the Convention is aimed to protect, to the same extent and with the same vigour the investor and the host State, not forgetting that to protect investments is to protect the general interest of development.' 
ICSID Convention, which otherwise could not have been negotiated under World Bank auspices. Although, under most BITs, States retain the right to admit foreign investment and are themselves probably best positioned to judge whether a specific investment is beneficial to their development, this does not solve the problem of excessively sweeping unforeseen protection ex post. Of course, the question of quis iudicabit is at the forefront of these problems. A more balanced interpretational approach might be achieved, as Judge Buergenthal suggests, by having stricter conflict of interest rules for arbitrators or by having a general appeals procedure within ICSID, as proposed by the ICSID Secretariat. ${ }^{108}$

A thorough economic analysis of international investment law is still lacking. There are intricate legal problems with a variety of actors that are difficult to model. In this article, for example, the 'black box' of State behaviour was not opened up in order to look at the internal processes that determine external policy. Nevertheless, an attempt has been made to identify the basic lines of economic logic governing this issue area.

108 ICSID Secretariat, Possible Improvements of the Framework for ICSID Arbitration, Discussion Paper (2004), available at: <http://www.worldbank.org/icsid/highlights/improvearb.pdf $>$. 